Technological University Dublin

DUBLIN

ARROW@TU Dublin

2010-04-01

\title{
A Study of the Physicochemical and Sensory Properties of Organic and Conventional Potatoes (Solanum tuberosum) Before and After Baking
}

\author{
Catherine Barry-Ryan \\ Technological University Dublin, Catherine.Barryryan@tudublin.ie \\ Roisin Burke \\ Technological University Dublin, roisin.burke@tudublin.ie \\ Clare Gilsenan \\ Technological University Dublin, Clare.gilsenan@tudublin.ie
}

Follow this and additional works at: https://arrow.tudublin.ie/schfsehart

Part of the Food Science Commons, and the Plant Sciences Commons

\section{Recommended Citation}

Barry-Ryan, C., Burke, R. \& Gilsenan, C. (2010). A study of the physicochemical and sensory properties of organic and conventional potatoes (Solanum tuberosum) before and after baking. Food Science \& Technology, 45(3), pp.475-481. doi:10.1111/j.1365-2621.2009.02148.x

This Article is brought to you for free and open access by the School of Food Science and Environmental Health at ARROW@TU Dublin. It has been accepted for inclusion in Articles by an authorized administrator of ARROW@TU Dublin. For more information, please contact arrow.admin@tudublin.ie, aisling.coyne@tudublin.ie, gerard.connolly@tudublin.ie.

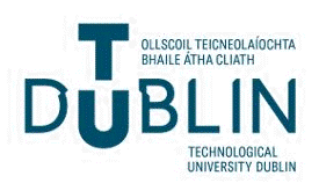




\title{
A study of the physicochemical and sensory properties of organic and conventional potatoes (Solanum tuberosum) before and after baking
}

\author{
International Journal of Food Science and Technology 2010, 45, 475-481
}

Clare Gilsenan, Roisın M. Burke \& Catherine Barry-Ryan

Dublin Institute of Technology, Cathal Brugha Street, Dublin 1, Ireland

\begin{abstract}
Summary The objective of this study was to investigate if there were any differences in the physicochemical and sensory properties of organic and conventional potatoes (cv. Orla). The conventional potatoes had a lower dry matter content $(P<0.05)$ and a slightly softer texture $(P \vee 0.05)$ than the organic potatoes. The trained panel perceived the conventional baked potato to be slightly softer, less adhesive and wetter than the organic baked potato $(P<0.05)$. However, the consumer panel found no significant difference between the organic and conventional baked potato samples for the sensory attributes of appearance, aroma, texture and taste acceptability.
\end{abstract}

Keywords Baked, conventional, organic, physicochemical analyses, potato, raw, sensory analysis.

Introduction

The potato (Solanum tuberosum L.) is a perennial plant from the Solanaceae family (Struik, 2007). It first originated in the Andes Mountains and was introduced to the European diet in the sixteenth century (Rocha et al., 2003). The potato is a very important food crop worldwide (Maga, 1994). Potatoes are the fourth most widely grown crop in the world after wheat, rice and maize (Vreugdenhil et al., 2007). In 2007, 325 million tonnes of potatoes were produced worldwide, which compares to 268 million tonnes in 1991 (FAOSTAT, 2008).

Baking is a very popular method of cooking for potatoes. In fact, it has been reported that the flavour of baked potatoes is considerably stronger than that of boiled potatoes (Oruna-Concha et al., 2002). The sensory attributes that define cooked potato quality are internal colour, intensity of aroma, mustiness, earthiness, hardness, adhesiveness, moistness, sweetness and aftertaste (Thybo \& Martens, 2000; Montouto-Grana et al., 2002).

Organically farmed foods have seen a significant rise in popularity worldwide in recent years (Willer et al.,
2009). Global sales of organically farmed produce have tripled in value from 10.8 billion euros in 1999 to 33.2 billion euros in 2007 (Sahota, 2009). However, a major challenge facing the organic food sector is the global economic slowdown. With the world currently going through an economic recession, the demand for organically farmed food is slowing (Sahota, 2009). Nonetheless, proponents of organic food still expect the organic market to perform well, albeit at a slower rate (Willer et al., 2009).

The popularity of organic foods maybe attributable to the perception that organic foods are healthier, safer and tastier than conventionally produced foods (Bourne \& Prescott, 2002; Magkos et al., 2006; Winter \& Davis, 2006). Organic agriculture is defined as a system of farming that avoids or largely excludes the use of synthetic fertilisers, herbicides, insecticides, fungicides, or any other pesticides, growth hormones or growth regulators (Codex Alimentarius Commission, 2001).

There is a growing volume of literature comparing the sensory quality of organically farmed and conventionally produced vegetables (Basker, 1992; Hajš lova et al., 2005; Wszelaki et al., 2005; Zhao et al., 2007). However, very little attention has been given to the comparative sensory properties of raw and baked organic and conventional potatoes. Therefore, the objectives of this 
study were to determine (1) whether there were any differences in the physicochemical components and sensory properties of organic and conventional potatoes (cv. Orla) before and after baking and (2) if so what is causing the difference(s).

Materials and methods

\section{Plant material}

Organically farmed and conventionally produced potatoes (cv. Orla) were collected from two sites in Navan, County Meath in Ireland. Both types of potato were grown in a clay loam soil. The organically farmed potatoes were fertilised with a composted farmyard manure at a rate of $25000 \mathrm{~kg}$ ha-1 annually. In addition to this, Burgundy (copper sulphate and washing soda) was applied to the crop at a rate of $15 \mathrm{~kg} \mathrm{ha-1}$ to protect the potato crop against potato blight. The land was used as grassland for 2 years prior to planting the organic seed. The organic growing system was approved by The Organic Trust of Ireland. The conventionally produced potatoes were fertilised with a synthetic N-P-K fertiliser (10-10-20) at rate of $1235 \mathrm{~kg}$ ha-1 annually. They were also sprayed with a commercial liquid copper fungicide blight spray. Both the farmyard manure and fertilisers were applied to the soil before sowing the organic and conventional potatoes. Both types of potato were planted during the month of June 2008 and were harvested during the months of October and November 2008. The potatoes for this study were selected according to commercial specifications (diameter $45-70 \mathrm{~mm}$, without discoloration, diseases or deformities). Average rainfall throughout the growing period was $104 \mathrm{~mm}$ and mean temperature was $13^{\circ} \mathrm{C}$ (Met Eireann, 2009).

\section{Sample preparation}

On arrival at the food processing laboratory, the potatoes were washed and rinsed with tap water and dried with cotton towels. The potatoes were stored in a dry store at $22^{\circ} \mathrm{C}$ for 1 day, until required for sensory analysis, instrumental analysis or baking. Prior to baking, the potatoes were pierced three times with a fork, to the depth of $1 \mathrm{~cm}$ and were covered with aluminium foil. The potato samples were then baked in an oven at $190{ }^{\circ} \mathrm{C}$ for $1 \mathrm{~h}$ (Oruna-Concha et al., 2002). The baked potatoes required for instrumental analysis were blast chilled to $4{ }^{\circ} \mathrm{C}$ (BQC 45, Foster, UK) and were stored in the refrigerator for a maximum of $1 \mathrm{~h}$. Those required for sensory evaluation were served directly from the oven. Internal temperatures of $84^{\circ} \mathrm{C}$ were recorded using a calibrated digital thermometer (Thermapen, West Sussex, UK). Batches of raw potatoes and baked potatoes were tested. In each case one new batch of organic and one new batch of conventional were tested, each week for 3 weeks during the end of October and the beginning of November 2008. Ten replicates from each batch were tested each time.

Physicochemical analyses

Colour analysis

Colour measurements were made using a Colorflex Spectrophotometer (Hunter Associates Laboratory Inc., Reston, VA, USA) which was calibrated with a white standard tile. The internal and external colour of both the raw potato $(n=30)$ and the cooked potato $(n=30)$ samples was measured at four random locations on the potato respectively. For the internal colour readings, the potatoes were cut in half from the bud end to the stem end. Colour measurements were taken at two peripheral and two central locations on each potato. The CIE L* (light/dark), a* (red/green) and b* (yellow/blue) values were obtained and from these readings chroma and hue angle were determined. Chroma, which indicates colour intensity was calculated using the equation $\left(a^{*}{ }_{2}+b^{*}\right)^{1 / 2}$, while hue, which signifies product colour was calculated using the equation $\tan -1\left(b^{\star} / a^{*}\right)$. This method was performed as previously described by Pardo et al. (2000).

Texture measurement The texture of both the raw potato $(n=30)$ and cooked potato $(\mathrm{n}=30)$ was measured using an Instron Universal Testing Machine (Model 4464; Instron Corp., Wycombe, UK). A thin longitudinal slice (bud end-stem end), _20 mm thick, was taken from each potato, using a handheld slicer (Gourmet V-Slicer, Nottingham, UK). The potato sample was punctured using a $7 \mathrm{~mm}$ diameter probe at a crosshead speed set at $200 \mathrm{~mm}$ min-1. A load cell of $500 \mathrm{~N}$ was used and four puncture tests were performed for each replicate. The maximum puncture force $(\mathrm{N})$ was recorded and the data was analysed using Bluehill software (Version 2.0.0, 2007). This method was performed as previously described by Abu-Ghannam \& Crowley (2006).

Determination of dry matter content The dry matter content of both the raw potato samples $(n=30)$ and the cooked potato samples $(n=30)$ was determined using a method as outlined by AOAC (1990). Two gram samples of potato were weighed and then dried in an oven at $105^{\circ} \mathrm{C}$ for $24 \mathrm{~h}$. The samples were then removed from the oven, cooled in a desiccator and weighed. The results were expressed as \% dry matter content.

$\mathrm{pH}$ measurement

The $\mathrm{pH}$ of the raw potato samples was determined using a method as described by Pardo et al. (2000). The $\mathrm{pH}$ was measured in the juice obtained after washing and 
crushing the samples (Breville Anthony Worrall Thompson Juicer, Lancashire, UK). Prior to conducting the $\mathrm{pH}$ analysis, the juice was filtered. The $\mathrm{pH}(\mathrm{n}=30)$ was measured at $20^{\circ} \mathrm{C}$ using a $\mathrm{pH}$ meter (Orion $\mathrm{pH}$ meter Model 420A, Waltham, MA, USA).

Ten gram samples of baked potato were blended with $20 \mathrm{~mL}$ of sonicated distilled water according to the method of Low et al. (2006). The $\mathrm{pH}(\mathrm{n}=30)$ of the unfiltered macerate was measured at $20{ }^{\circ} \mathrm{C}$ using a calibrated pH meter (Orion pH meter Model 420A).

${ }^{\circ}$ Brix measurements

The oBrix of the raw potato samples $(n=30)$ was determined using a method as described by Pardo et al. (2000). The oBrix was measured in the juice obtained after washing and crushing the samples (Breville Anthony Worrall Thompson Juicer, Lancashire, UK). Prior to measuring the oBrix, the juice was filtered. The oBrix content was measured at $20^{\circ} \mathrm{C}$ using a refractometer (VWR Handheld Refractometer, 0-50\% Brix ATC, Germany).

The oBrix of the baked potato samples $(n=30)$ was determined by blending $10 \mathrm{~g}$ of baked potato with $20 \mathrm{~mL}$ of sonicated distilled water. The oBrix of the unfiltered macerates was measured using a refractometer (VWR Handheld Refractometer, 0-50\% Brix ATC, Germany) at $20^{\circ} \mathrm{C}$.

\section{Sensory analysis}

Trained panel Quantitative Descriptive Analysis (QDA) was used to assess the organic and conventional potatoes. All assessors were trained according to international standards (ISO, 1993). Ten candidates (seven females, three males) were prescreened on the basis of availability, general health and food habits. All ten candidates successfully completed all flavour and texture acuity tests. Ten training sessions were held in which the tasting procedures, development of sensory descriptors and appropriate scoring procedures were emphasised. For the sensory tests, the assessors worked in a single booth under defined conditions of $20^{\circ} \mathrm{C}$ and artificial daylight. The sensory tests were delivered using Compusense five (Version 4.4; Compusense Inc., Guelph, ON, Canada). The assessors received whole samples for the analysis of raw $(n=30)$ and baked $(n=30)$ potatoes. Each of the ten panelists performed the tests on each of the 3 weeks, for each batch of harvest. The samples were served on white paper plates coded with three digit random numbers and the order of presentation of the samples was completely randomised. The assessors were instructed to evaluate the appearance, aroma and textural attributes of the raw potato samples, and to assess the appearance, aroma, texture and taste attributes of the baked potato samples, before marking their scores. The assessors recorded their results on ninepoint line scales. Sensory attributes were selected from those previously reported in the literature (Thybo \& Martens, 2000; Montouto-Grana et al., 2002; Meilgaard et al., 2007). For the raw potato samples, the panel evaluated two appearance attributes (external colour and internal colour), three aroma attributes (intensity of aroma, mustiness and earthiness), and two texture attributes (hardness and moistness).

For the baked potato samples, the panel evaluated one appearance attribute (intensity of internal colour), three aroma attributes (intensity of aroma, mustiness and earthiness), three texture attributes (hardness, adhesiveness and moistness) and two taste attributes (sweetness and aftertaste). Water was provided for assessors to cleanse their palates in between samples.

Consumer panel

Eighty consumers were recruited among the staff and students of Dublin Institute of Technology, Ireland. Consumers were selected on the basis of being regular consumers of potatoes. The sensory panel consisted of $40 \%$ males and $60 \%$ females. At the time of the consumer sensory evaluation, samples were served directly from the oven to the consumers. The organic and conventional potatoes used for the consumer sensory analysis were taken from the second batch. The sensory method was performed as described by Meilgaard et al. (2007). The panel received two samples (one organic baked potato and one conventional baked potato) in simultaneous presentation, half in the order $\mathrm{A}-\mathrm{B}$, the other half $\mathrm{B}-\mathrm{A}$. Panelists were purposely not told that they would be evaluating baked organic and conventional potatoes until they had completed scoring. This was done to eliminate the possibility of any potential bias that may have occurred had panelists been informed of the nature of the trial. Samples were served on white paper plates coded with three digit random numbers. The panelists worked in a single booth under defined conditions of $20{ }^{\circ} \mathrm{C}$ and artificial daylight. Firstly, the panelists were instructed to evaluate the colour, aroma, texture and taste acceptability of the baked potatoes on a ninepoint hedonic scale, where $9=$ 'like extremely' and 1 = 'dislike extremely'. Then the panelists were required to participate in a preference test. The panelists were required to cleanse their palates with water in between samples.

\section{Data analysis}

The physicochemical and sensory data was analysed using spss 15.0 (SPSS Inc., Chicago, IL, USA). All instrumental and sensory data were subject to independent t-tests to assess the significance of treatment means at the $5 \%$ significance level. 
Potato quality is affected by a wide range of factors, such as choice of cultivar, geographical location, climatic conditions and pre- and post harvesting practices (Vos \& Haverkort, 2007). However, the influence of these variables was minimised in this study.

Colour values of organic and conventional potatoes before and after baking

The results of the colour analysis for the organic and conventional raw potato samples are presented in Table 1. A comparison between both types of raw potato skin colour found no significant difference for Hunter $L^{*}, a^{*} b^{*}$ values. Similarly, no significant differences were observed between the organic and conventional raw potato skin colour for chroma and hue. This would suggest that the cultivation method had very little effect on the skin colour of the potato.

As with the skin colour, no significant differences were recorded for $L^{*}, a^{*}, b^{\star}$, chroma and hue colour values between the flesh colour of the organic and conventional raw potato samples.

For the baked potatoes, no statistically significant differences were observed between the external colour and between the internal colour of the organic and conventional potato samples for any of the colour parameters (Table 2).

Table 1 Physicochemical characteristics of organic and conventional raw potatoes (cv. Orla)

\begin{tabular}{lrr}
\hline Physicochemical analysis & Organic potatoes & Conventional potatoes \\
\hline Colour parameters & & \\
External $L^{*}$ & $73.7 \pm 2.5^{*}$ & $74.2 \pm 2.0^{*}$ \\
External $a^{*}$ & $5.1 \pm 0.7^{*}$ & $5.0 \pm 0.6^{*}$ \\
External $b^{*}$ & $31.1 \pm 1.6^{*}$ & $31.3 \pm 1.2^{*}$ \\
External chroma & $31.5 \pm 1.6^{*}$ & $31.7 \pm 1.2^{*}$ \\
External hue angle & $80.6 \pm 1.3^{*}$ & $80.9 \pm 1.2^{*}$ \\
Intemal $L^{*}$ & $71.9 \pm 1.7^{*}$ & $72.1 \pm 1.6^{*}$ \\
Intemal $a^{*}$ & $-0.2 \pm 0.1^{*}$ & $-0.12 \pm 0.1^{*}$ \\
Intemal $b^{*}$ & $22.3 \pm 0.7^{*}$ & $22.5 \pm 0.8^{*}$ \\
Intemal chroma & $22.3 \pm 0.7^{*}$ & $22.5 \pm 0.8^{*}$ \\
Intemal hue angle & $90.6 \pm 0.3^{*}$ & $90.5 \pm 0.3^{*}$ \\
Textural parameter & & \\
Max. puncture force $(\mathrm{N})$ & $32.1 \pm 1.6^{*}$ & $30.4 \pm 1.4^{\mathrm{b}}$ \\
Dry matter content & & \\
\% Dry matter & $21.8 \pm 0.9^{*}$ & $20.1 \pm 0.8^{\mathrm{b}}$ \\
Soluble solids content & & \\
'Brix & $4.1 \pm 0.5^{*}$ & $4.2 \pm 0.5^{*}$ \\
Acidity values & & $5.8 \pm 0.0^{*}$ \\
pH & $5.7 \pm 0.0^{*}$ & \\
\hline
\end{tabular}

Data are the mean values ( $₫$ SD) of thirty organic and thirty conventional raw potato (cv. Orla) samples. Values bearing different superscripts are significantly different $(P \leq 0.05)$.
Table 2 Physicochemical characteristics of organic and conventional baked potatoes ( $c v$. Orla)

\begin{tabular}{lrr}
\hline Physicochemical analysis & Organic potatoes & Conventional potatoes \\
\hline Colour parameters & & \\
External $L^{*}$ & $56.1 \pm 2.0^{*}$ & $55.5 \pm 1.7^{*}$ \\
External $a^{*}$ & $9.1 \pm 0.7^{*}$ & $9.4 \pm 0.7^{*}$ \\
External $b^{*}$ & $33.0 \pm 1.2^{*}$ & $33.1 \pm 1.2^{*}$ \\
External chroma & $34.3 \pm 1.2^{*}$ & $34.4 \pm 1.2^{*}$ \\
External hue angle & $74.6 \pm 1.2^{*}$ & $74.1 \pm 1.1^{*}$ \\
Internal $L^{*}$ & $77.3 \pm 1.8^{*}$ & $77.5 \pm 1.3^{*}$ \\
Internal $a^{*}$ & $-3.6 \pm 0.3^{*}$ & $-3.5 \pm 0.2^{*}$ \\
Internal $b^{*}$ & $18.9 \pm 0.7^{*}$ & $19.1 \pm 0.5^{*}$ \\
Internal chroma & $19.3 \pm 0.7^{*}$ & $19.3 \pm 0.6^{*}$ \\
Internal hue angle & $100.9 \pm 0.7^{*}$ & $100.4 \pm 0.5^{*}$ \\
Textural parameter & & \\
Max. puncture force (N) & $2.2 \pm 0.5^{*}$ & $1.6 \pm 0.4^{*}$ \\
Dry matter content & & \\
\% Dry matter & $23.9 \pm 1.3^{*}$ & $22.3 \pm 1.3^{\mathrm{b}}$ \\
Soluble solids content & & \\
'Brix & $3.4 \pm 0.6^{*}$ & $3.5 \pm 0.6^{*}$ \\
Acidity values & & \\
pH & $5.8 \pm 0.0^{*}$ & $5.8 \pm 0.0^{*}$ \\
\hline
\end{tabular}

Data are the mean values $( \pm S D$ ) of thirty organic and thirty conventional baked potato samples. Values bearing different superscripts are significantly different $(P \leq 0.05)$.

Dry matter values of organic and conventional potatoes before and after baking

The dry matter content of a potato usually ranges from approximately 18-26\% (Burton, 1989). It is an incredibly important parameter of potato quality, as it influences the effects of cooking on sensory attributes, in particular texture (Taylor et al., 2007).

A comparison between the raw organic and conventional potato samples found a significant difference ( $P £ 0.05)$ for dry matter content (Table 1 ). The raw conventional potato samples had a lower dry matter content $(P £ 0.05)$ than the raw organic potato samples. These results are in agreement with the findings of previous studies conducted on the dry matter content of organic and conventional potatoes (Hajš lova et al., 2005; Maggio et al., 2008). The low dry matter content of the raw conventional potato sample may have occurred due to the rate of nitrogen fertilisation. O'Beirne \& Cassidy (1990) conducted a study on the effects of nitrogen fertiliser on the dry matter content of potatoes and reported that the dry matter content of potatoes was significantly reduced by fertilising crops with quantities of nitrogen with values in the range of $150 \mathrm{~kg}$ ha-1 or higher. Burton (1989) reported that the application of Phosphorus and Potassium do not appear to effect the dry matter content of potatoes. In this study the organic crop was fertilised with a composted farmyard manure at a rate of $25000 \mathrm{~kg}$ ha-1 annually. One tonne of organic farmyard 
manure contains $4.5 \mathrm{~kg} \mathrm{~N}$ and $1.2 \mathrm{~kg} \mathrm{P}$ (Statutory Instrument, 2009). Therefore, this organic farmyard manure supplied the crop with $113 \mathrm{~kg} \mathrm{~N}$ ha-1 and $30 \mathrm{~kg}$ $P$ ha-1. While the conventional crop was fertilised with a synthetic N-P-K fertiliser at a rate of (10-10-20) $1235 \mathrm{~kg}$ ha-1 annually. This would mean that $124 \mathrm{~kg} \mathrm{~N}$ ha-1, 124 kg P ha-1 and 248 kg K ha-1 was incorporated into the soil of the conventional crop. However, according to Statutory Instrument No. 101 of 2009, approximately $25 \%$ of the Nitrogen and $100 \%$ of the Phosphorus is available from the organic farmyard manure, whereas $100 \%$ of the Nitrogen and $100 \%$ of the Phosphorus is available from the chemical fertiliser. Therefore, this means that only $28 \mathrm{~kg} \mathrm{~N}$ ha-1 and $30 \mathrm{~kg} \mathrm{P}$ ha-1 was available to the organic potato crop, while $124 \mathrm{~kg} \mathrm{~N}$ ha-1 and $124 \mathrm{~kg} \mathrm{P}$ ha-1 was available to the conventional potato crop. This shows that the conventional potato crop was exposed to higher quantities of $\mathrm{N}$ and $\mathrm{P}$ per hectare compared to the organic potato crop (an additional of $96 \mathrm{~kg} \mathrm{~N}$ ha-1 and $94 \mathrm{~kg} \mathrm{P}$ ha-1 respectively). This may have caused the conventional potatoes to have less dry matter than the organic potatoes. According to Burke (2003) the application of large quantities of Nitrogen increases the size of the canopy during the early growth phase of the potato, which in turn diverts dry matter into the production of excess leaf and stem to the detriment of the tuber.

In addition to this, regardless of the type of nitrogen fertiliser (inorganic, organic manures), plants use nitrogen only in the form of nitrate ( $\left.\mathrm{NO}_{3}-\right)$ and ammonium $\left(\mathrm{NH}_{4}+\right)$. According to Herrera et al. (1999) nitrogen containing compounds are broken down into free ammonium, which is converted into ammonia and ammonia salts. Microorganisms 'fix Nitrogen' by breaking down ammonia into nitrite ( $\left.\mathrm{NO}_{2-}\right)$ and then to nitrate ( $\left.\mathrm{NO}_{3-}\right)$. Nitrate ( $\left.\mathrm{NO}_{3-}\right)$ and Ammonium $\left(\mathrm{NH}_{4}+\right)$ are dissolved in the soil water and taken up by the plant. Nutrients from organic fertilisers are released more slowly and steadily to the plant (Montagu \& Goh, 1990), whereas synthetic chemical fertilisers offer more readily available sources of nitrogen, to accelerate plant growth (Faller \& Fialho, 2009).

The effect of baking on the dry matter content of the organic and conventional potatoes can be found in Table 2. A statistically significant difference $(P<0.05)$ was documented between the organic and conventional baked potatoes for dry matter content, with the conventional potato having a lower dry matter content. This was expected as the raw conventional potatoes had a lower dry matter content than the raw organic potatoes.

\section{Texture values of organic and conventional potatoes after} before and baking

Maximum puncture force values for raw organic and raw conventional potato samples are shown in Table 1.
A comparison between both type of raw potato found a significant difference $(P<0.05)$ for maximum puncture force. The conventional potatoes were significantly softer $(P<0.05)$ than the organic potatoes. This result was attributed to the dry matter content which was significantly higher in the organic potatoes. Dry matter is of particular importance with regard to texture. Gopal \& Khurana (2006) reported that dry matter is generally correlated with texture.

A comparison between the baked organic and baked conventional potato showed a statistically significant difference $(P<0.05)$ for the maximum puncture force (Table 2). The conventional baked potato was softer than the organic baked potato. This is as expected as a significant difference was already observed between the organic and conventional raw potato

\section{$\mathrm{pH}$ values of organic and conventional potatoes before and after baking}

No significant difference was recorded between the organic and conventional raw potato samples, nor between the organic and conventional baked potatoes for $\mathrm{pH}$ (Tables 1 and 2). This would suggest that the growing systems used here had little effect on the $\mathrm{pH}$ value for these the potatoes.

\section{${ }^{\circ}$ Brix values of organic and conventional potatoes before and after baking}

The sugar content of the organic and conventional potatoes was measured using oBrix. A comparison between both organic and conventional raw potato found no significant difference for oBrix value. The findings of Maggio et al. (2008) support our results. In their study, they observed no significant difference between the organic and conventional potato samples for sucrose and glucose content. However, they did report a small but significant difference for fructose. In their study, the conventional potatoes had a higher fructose content (an increase of $0.10 \mathrm{~g} 100 \mathrm{~g}-1 \mathrm{FW}$ ). For the baked potatoes, no significant differences were observed between the organic and conventional potato samples for oBrix.

\section{Sensory analysis of organic and conventional potatoes before and after baking}

The effect of the growing systems on the sensory quality of the raw organic and conventional potatoes by a trained panel are shown in Table 3. No significant differences were found between the organic and conventional raw potato samples for the sensory attributes of colour, aroma and texture. Both types of raw potato were described as having a creamy white external colour and a yellow internal colour. The strength of raw potato 
Table 3 Sensory evaluation scores of organic and conventional raw potatoes (cv. Orla) by the trained panel

\begin{tabular}{lll}
\hline Sensory parameters & $\begin{array}{l}\text { Organic } \\
\text { potatoes }\end{array}$ & $\begin{array}{l}\text { Conventional } \\
\text { potatoes }\end{array}$ \\
\hline External colour & $1.9 \pm 1.0 \mathrm{a}$ & $2.0 \pm 1.0 \mathrm{a}$ \\
Internal colour & $1.5 \pm 0.8 \mathrm{a}$ & $1.6 \pm 0.8 \mathrm{a}$ \\
Raw potato aroma & $3.3 \pm 1.5 \mathrm{a}$ & $2.9 \pm 1.2 \mathrm{a}$ \\
Mustiness & $2.7 \pm 1.3 \mathrm{a}$ & $2.8 \pm 1.3 \mathrm{a}$ \\
Earthiness & $3.2 \pm 1.4 \mathrm{a}$ & $3.6 \pm 1.6 \mathrm{a}$ \\
Hardness & $7.7 \pm 1.1 \mathrm{a}$ & $7.8 \pm 1.0 \mathrm{a}$ \\
Moistness & $6.6 \pm 1.1 \mathrm{a}$ & $6.4 \pm 1.1 \mathrm{a}$ \\
& & \\
\hline
\end{tabular}

Data are mean values $( \pm S D)$ of thirty organic and thirty conventional raw potatoes. Values bearing different superscripts are significantly different $(P<0.05)$ for each attribute.

aroma was considered to be moderate for both types of raw potato, while mustiness was perceived to be very slight, as was intensity of earthiness. In addition to this, both types of potato were perceived to be hard and were seen to display a moderate level of surface moisture, once cut.

Statistically significant differences ( $P £ 0.05$ ) were observed for the textural attributes of hardness, adhesiveness and moistness between the organic and conventional baked potato samples. The trained panel found the baked conventional potatoes to be softer $(P £ 0.05)$, less adhesive ( $P £ 0.05)$ and wetter ( $P £ 0.05$ ) than the baked organic potatoes (Table 4). These findings are supported by the instrumental results for dry matter and firmness. The baked conventional potatoes had a lower dry matter content and required a lower puncture force $(\mathrm{N})$ to perforate the samples. No significant difference was reported between the organic and conventional baked potatoes for colour, aroma or taste attributes. These findings concur with the instru-

Table 4 Sensory evaluation scores of organic and conventional baked potatoes (cv. Orla) by the trained panel.

\begin{tabular}{lll}
\hline Sensory parameters & $\begin{array}{l}\text { Organic } \\
\text { potatoes }\end{array}$ & $\begin{array}{l}\text { Conventional } \\
\text { potatoes }\end{array}$ \\
\hline Internal colour & $1.5 \pm 0.8 \mathrm{a}$ & $1.4 \pm 0.7 \mathrm{a}$ \\
Cooked potato aroma & $6.4 \pm 1.5 \mathrm{a}$ & $6.3 \pm 1.5 \mathrm{a}$ \\
Mustiness & $2.9 \pm 1.4 \mathrm{a}$ & $2.9 \pm 1.4 \mathrm{a}$ \\
Earthiness & $3.9 \pm 1.3 \mathrm{a}$ & $3.6 \pm 1.1 \mathrm{a}$ \\
Hardness & $3.5 \pm 0.9 \mathrm{a}$ & $2.5 \pm 0.9 \mathrm{~b}$ \\
Adhesiveness & $5.2 \pm 1.3 \mathrm{a}$ & $4.3 \pm 1.4 \mathrm{~b}$ \\
Moistness & $2.8 \pm 1.4 \mathrm{a}$ & $3.9 \pm 1.4 \mathrm{~b}$ \\
Sweetness & $3.4 \pm 1.0 \mathrm{a}$ & $3.5 \pm 1.0 \mathrm{a}$ \\
Aftertaste & $3.2 \pm 1.2 \mathrm{a}$ & $3.3 \pm 1.2 \mathrm{a}$ \\
& &
\end{tabular}

Data are mean values $( \pm \mathrm{SD})$ of thirty organic and thirty conventional baked potatoes. Values bearing different superscripts are significantly different $(P<0.05)$ for each attribute.
Table 5 Consumer sensory evaluation of organic and conventional baked potatoes (cv. Orla)

\begin{tabular}{|c|c|c|}
\hline $\begin{array}{l}\text { Acceptability } \\
\text { attributes }\end{array}$ & $\begin{array}{l}\text { Organic } \\
\text { potatoes }\end{array}$ & $\begin{array}{l}\text { Conventional } \\
\text { potatoes }\end{array}$ \\
\hline Appearance & $7.0 \pm 1.4 a$ & $7.1 \pm 1.6 \mathrm{a}$ \\
\hline Aroma & $7.2 \pm 1.3 a$ & $7.2 \pm 1.4 \mathrm{a}$ \\
\hline Texture & $6.8 \pm 1.6 a$ & $7.0 \pm 1.5 \mathrm{a}$ \\
\hline Taste & $7.0 \pm 1.6 \mathrm{a}$ & $7.2 \pm 1.6 \mathrm{a}$ \\
\hline
\end{tabular}

Data are the mean values $( \pm S D)$ of eighty organic and eighty conventional baked potatoes. Values bearing different superscripts are significantly different $(P<0.05)$ for each attribute.

mental results for colour, oBrix and $\mathrm{pH}$. In contrast, Thybo et al. (2001) reported minor differences in the colour, off odour, moistness, mealiness and graininess of boiled potatoes, which had been subjected to six different organic treatments. The results of the consumer sensory evaluations on the organic and conventional baked potatoes did not show any statistically significant differences for appearance, aroma, texture and taste acceptability attributes (Table 5). The consumers indicated they 'liked moderately' the appearance, aroma, texture and taste acceptability attributes of the organic and conventional baked potatoes. Furthermore, the results of the paired preference test revealed that thirtythree consumers $(41 \%)$ preferred the organic potatoes, whereas forty-seven consumers (59\%) preferred the conventional potatoes. This result is sufficient to conclude that there was no statistically significant difference for preference between the organic and conventional baked potatoes among the consumer panel in this study. These results are in agreement with the findings of Hajs ${ }^{2}$ lova et al. (2005) and Wszelaki et al. (2005), who also reported no significant differences between organic and conventional cooked potatoes for appearance, aroma, texture and taste attributes

\section{Conclusions}

Organic growing conditions appear to have a significant impact on the texture of raw and baked potatoes (cv. Orla), but do not appear to affect appearance, taste or consumer acceptability of baked potatoes.

\section{References}

Abu-Ghannam, N. \& Crowley, H. (2006). The effect of low temperature blanching on the texture of whole processed new potatoes. Journal of Food Engineering, 74, 335-344.

AOAC. (1990). Official Methods of Analysis of AOAC International, 15th edn. Washington, DC: AOAC International.

Basker, D. (1992). Comparison of taste quality between organically and conventionally grown fruits and vegetables. American Journal of Alternative Agriculture, 7, 129-136. 
Bourne, D. \& Prescott, J. (2002). A comparison of the nutritional value, sensory qualities, and food safety of organically and conventionally produced foods. Critical Reviews in Food Science and Nutrition, 42, 1-34.

Burke, J. (2003). Growing the Potato Crop. Agriculture and Food Development Authority, Teagasc. Available from: http://www teagasc.ie/publications/2003/conferences/potato/paper 02.asp [Accessed 22 August 2009]

Burton, W.G. (1989). The Potato, 3rd edn. New York: Longman Scientific and Technical.

Codex Alimentarius Commission (2001). Guidelines for the Production, Processing, Labelling and Marketing of Organically Produced Food. Rome: Joint Food and Agriculture Organisation/World Health Organisation

Faller, A.L.K. \& Fialho, E. (2009). The antioxidant capacity and polyphenol content of organic and conventional retail vegetables after domestic cooking. Food Research International, 42, 210-215.

FAOSTAT. (2008). Potato World: World Potato Production. Available from: http://www.potato2008.org/en/world/index.html [Accessed 29/10/2008]

Gopal, J. \& Khurana, S.M.P. (2006). Handbook of Potato Production, Improvement, and Postharvest Management. New York: Haworth Press.

Hajs` lova, J., Schulzova, V., Slanina, P., Janne, K., Hellenas, K.E. \&" Andersson, $\mathrm{CH}$. (2005). Quality of organically and conventionally grown potatoes: four-year study of micronutrients, metals, secondary metabolites, enzymic browning and organoleptic properties.

Food Additives and Contaminants, 22, 514-534.

Herrera, J.L.B., Perez, M.P.Y., Turon, J.G. et al. (1999). Handbook of Agriculture. New York: Marcel Dekker.

ISO. (1993). Sensory analysis- general guidance for the selection, training and monitoring of assessors-ISO8586-1, Geneva, Switzerland.

Low, M.Y., Koutsidis, G., Parker, J.K., Elmore, S.J., Dodson, A.T. \& Mottram, D.S. (2006). Effect of citric acid and glycine addition on acrylamide and flavour in a potato model system. Journal of Agricultural and Food Chemistry, 54, 5976-5983.

Maga, J.A. (1994). Potato flavour. Food Review International, 10, 1-48.

Maggio, A., Carillo, P., Bulmetti, G.S., Fuggi, A., Barbieri, G. \& De Pascale, S. (2008). Potato yield and metabolic profiling under conventional and organic farming. European Journal of Agronomy, 28, 343-350.

Magkos, F., Arvaniti, F. \& Zampelas, A. (2006). Organic food: Buying more safety or just peace of mind? A critical review of the literature Critical Reviews in Food Science and Nutrition, 46, 23-56.

Meilgaard, M.C., Civille, G.V. \& Carr, B.T. (2007). Sensory Evaluation Techniques, 4th edn. Boca Raton: CRC Press. Met Eireann. (2009). Monthly Weather Summaries May-October 2008. Dublin: Met Eireann. Available from: http://www.met.ie/agri-environment/agri_agri.asp [Accessed 20/05/2009]

Montagu, K.D. \& Goh, K.M. (1990). Effects of forms and rates of organic and inorganic nitrogen fertilisers on yield and some quality indices of tomatoes (Lycoperiscon esculentum, Miller). New Zealand Journal of Crop Horticultural Science, 18, 31-37.

Montouto-Grana, M., Fernandez-Fernandez, E., Vazquez-Oderiz, M.L. \& Romero-Rodrí guez, M.A. (2002). Development of a sensory profile for specific denomination "Galician potato". Food Quality and Preference, 13, 99-106.
O'Beirne, D. \& Cassidy, J.C. (1990). Effects of nitrogen fertilizer on yield, dry matter content and flouriness in potatoes. Journal of the Science of Food and Agriculture, 52, 351-363.

Oruna-Concha, M.J., Bakker, J. \& Ames, J.M. (2002). Comparison of the volatile components of two cultivars of potato cooked by boiling, conventional baking and microwave baking. Journal of the Science of Food and Agriculture, 82, 1080-1087.

Pardo, J.E., Alvarruiz, A., Perez, J.I., Gomez, R. \& Varon, R. (2000) Physical-chemical and sensory quality evaluation of potato varieties (Solanum tuberosum L.). Journal of Food Quality, 23, 149-160.

Rocha, A.M.C.N., Coulon, E.C. \& Morais, A.M.M.B. (2003). Effects of vacuum packaging on the physical quality of minimally processed potatoes. Food Service Technology, 3, 81-88.

Sahota, A. (2009). The Global Market for Organic Food and Drink In: The World of Organic Agriculture. Statistics and Emerging Trends (edited by H. Willer \& L. Kilcher). Pp. 59-63. Bonn: International Federation of Organic Agricultural Movement.

Statutory Instrument. (2009). European Communities (Good Agricultural Practice for Protection of Waters) Regulations 2009, SI. No.101 of 2009. Dublin: Stationary Office.

Struik, P.C. (2007). Above-ground and below-ground plant development. In: Potato Biology and Biotechnology- Advances and Perspectives (edited by D. Vreugdenhil, J. Bradshaw, C. Gebhardt, F. Govers, D.L. MacKerron, M.A. Taylor \& H.A. Ross). Pp. 219-236. Oxford: Elsevier.

Taylor, M.A., McDougall, G.J. \& Stewart, D. (2007). In: Potato Biology and Biotechnology - Advances and Perspectives (edited by D. Vreugdenhil, J. Bradshaw, C. Gebhardt, F. Govers, D.L. MacKerron, M.A. Taylor \& H.A. Ross). Pp. 525-538. Oxford: Elsevier.

Thybo, A.K. \& Martens, M. (2000). Analysis of sensory assessors in texture profiling of potatoes by multivariate modeling. Food Quality and Preference, 11, 283-288.

Thybo, A.K., Mølgaard, J.P. \& Kidmose, U. (2001). Effect of different organic growing conditions on the quality of cooked potatoes. Journal of the Science of Food and Agriculture, 82, 12-18.

Vos, J. \& Haverkort, A.J. (2007). Water availability and potato crop performance. In: Potato Biology and Biotechnology- Advances and Perspectives (edited by D. Vreugdenhil, J. Bradshaw, C. Gebhardt, F. Govers, D.L. MacKerron, M.A. Taylor \& H.A. Ross). Pp. 333351. Oxford: Elsevier.

Vreugdenhil, D., Bradshaw, J., Gebhardt, C. et al. (2007). Potato Biology and Biotechnology - Advances and Perspectives. Oxford: Elsevier.

Willer, H., Rohwedder, M. \& Wynen, E. (2009). Organic Agriculture Worldwide: Current Statistics. In: The World of Organic Agriculture. Statistics and Emerging Trends (edited by H. Willer \& L. Kilcher). Pp. 25-58. Bonn: International Federation of Organic Agricultural Movement.

Winter, C.K. \& Davis, S.F. (2006). Organic food. Journal of Food Science, 71, R117-R124.

Wszelaki, A.L., Delwiche, J.F., Walker, S.D., Liggett, R.E., Scheerens, J.C. \& Kleinhenz, M.D. (2005). Sensory quality and mineral and glycoalkaloid concentrations in organically and conventionally grown redskin potatoes (Solanum tuberosum). Journal of the Science of Food and Agriculture, 85, 720-726.

Zhao, X., Chambers, IV, E., Matta, Z., Loughin, T.M. \& Carey, E.E. (2007). Consumer sensory analysis of organically and conventionally grown vegetables. Journal of Food Science, 72, S87-S91. 